\title{
Effect of a lignan (HPMF) on RNA synthesis in the rat uterus*
}

\author{
A. P. Waters and J. T. Knowler \\ Department of Biochemistry, University of Glasgow, Glasgow G12 8QQ, U.K.
}

\begin{abstract}
Summary. HPMF, at doses of $0.01-1 \mathrm{mg} / \mathrm{kg}$, had no effect on uterine RNA synthesis over a period of $24 \mathrm{~h}$. It significantly depressed oestrogen-stimulated RNA synthesis if administered $22 \mathrm{~h}$ before oestradiol but not if given $10 \mathrm{~h}$ before or together with the hormone.
\end{abstract}

\section{Introduction}

The lignan, trans ( \pm )-3,4-bis [(3-hydroxyphenyl) methyl] dehydro-3-furanone (HPMF) has aroused considerable interest since its detection in the urine of humans, baboons, vervet monkeys and rats (Setchell et al., 1980). Because in women it is excreted in a biphasic manner with a peak in the luteal phase of the ovulatory cycle and also in relatively high levels in the first trimester of pregnancy, Stitch et al. (1980) have suggested that the substance may have a biological role. Analogies have been drawn with similar plant substances which control cell division and a mode of action for HPMF, as a menstrual hormone controlling the length of the luteal phase of the cycle, has been suggested (Setchell et al., 1980). The structures of HPMF and a number of anti-cancer drugs, believed to act by binding to DNA and stopping the growth of cancer cells, have also been compared (Setchell et al., 1980).

However, the lignan is a product of gut bacteria (Axelson \& Setchell, 1981): rats with their ovaries removed still excreted HPMF while those brought up in a germ-free environment did not. These findings do not, however, detract from the interest of the original findings. It is still necessary to explain the cyclic nature of HPMF secretion and it is still possible that HPMF is a breakdown product of a hormonal substance. Even if it is solely a product of gut bacteria, it is still of interest to know whether it exerts any effect on uterine growth.

The preparation of the uterus for a possible pregnancy is initiated by oestrogen which provokes hypertrophy followed by hyperplasia. One of the first detectable events in this process is the stimulated synthesis of RNA. When oestradiol-17 $\beta$ is administered to immature rats, stimulated RNA synthesis can be detected within 30 min (Aziz \& Knowler, 1978); peak values, 6-10-fold those of unstimulated animals, occur 2-4 h after injection (Knowler \& Smellie, 1971; Knowler, Borthwick \& Smellie, 1975). Here we describe an analysis of the effects of HPMF on uterine RNA synthesis and on oestrogen-stimulated uterine RNA synthesis in rats.

\section{Materials and Methods}

The source of immature rats, the administration of oestradiol-17 $\beta$ in corn oil, the administration of radioactive precursor and the preparation of acid-soluble and acid-insoluble fractions have all been previously described (Knowler \& Smellie, 1971; Waters \& Knowler, 1981).

* Reprint requests to Dr J. T. Knowler. 
HPMF was a generous gift from Organon Laboratories. It was administered by subcutaneous injection to $18-21$-day-old rats in $0.1 \mathrm{ml}$ corn oil.

\section{Results and Discussion}

Groups of 6 rats, weighing $30-35 \mathrm{~g}$, received $0 \cdot 3,3 \cdot 0$ or $30 \mu \mathrm{g} \mathrm{HPMF} / \mathrm{rat}$ at various times up to $24 \mathrm{~h}$ before death. Incorporation of precursor into uterine RNA and into precursor pools was then monitored. No significant effect of the lignan on the basal levels of uterine RNA synthesis was detected. Thus in 6 separate experimental determinations at each dose of HPMF, RNA synthesis did not deviate significantly from that of untreated controls, i.e. $0.33 \pm 0.06 \mathrm{c.p} . \mathrm{m} . / \mu \mathrm{g}$ DNA with an average recovery of $405 \mu \mathrm{g}$ DNA/uterus. Oestrogen alone induced a dramatic stimulation of uterine RNA synthesis which, by $2 \mathrm{~h}$ after administration, was nearly 11 -fold greater than that of unstimulated controls (Text-fig. 1). Precursor pool sizes, measured as radioactivity in the acid-soluble fraction, were also stimulated but to a much smaller extent. These results confirm our previous findings (Knowler \& Smellie, 1971; Waters \& Knowler, 1981). HPMF had no significant effect on the stimulation by oestradiol when administered at the same time as oestradiol or up to $12 \mathrm{~h}$ before it, but when given $24 \mathrm{~h}$ before death ( $22 \mathrm{~h}$ before oestradiol) there was a significant and consistent depression of RNA synthesis such that the stimulation due to oestrogen was reduced from 11 -fold to 6 -fold $(P=0 \cdot 04)$. It is difficult to relate the levels of HPMF we have administered to the measurements of physiological levels in rats which have been based on excretion in urine. It would, however, be advisable to repeat these experiments with higher doses of HPMF to see whether the effects are greater. Such experiments are at present beyond our resources.

HPMF bears little obvious structural similarity to oestrogens. However, the geometry of the molecule does present similarities with that of the anti-oestrogens, tamoxifen, clomiphene and nafoxidine, molecules which, despite having very different two-dimensional structures from

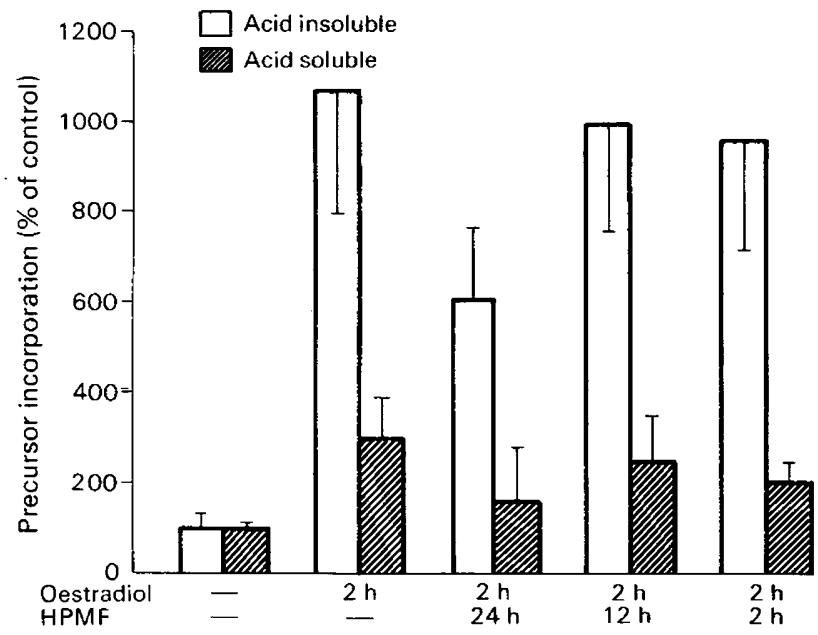

Text-fig. 1. Effect of HPMF $(0.3 \mu \mathrm{g} /$ rat, s.c. in $0.1 \mathrm{ml}$ corn oil) on the acid-insoluble and acid-soluble incorporation of $\left[5,6-{ }^{3} \mathrm{H}\right]$ uridine $(10 \mu \mathrm{Ci} / \mathrm{rat})$ into the DNA of the uterine tissue of immature rats (18-21 days of age, $30-35 \mathrm{~g})$. Oestradiol $-17 \beta(1.0 \mathrm{~g} / \mathrm{rat}$, s.c. in $0.1 \mathrm{ml}$ corn oil) was given $2 \mathrm{~h}$ before death. Control animals received $0.1 \mathrm{ml}$ corn oil. Results were calculated as c.p.m./ $\mu \mathrm{g}$ DNA and plotted as a percentage of the incorporation into control animals $(0.33 \pm$ 0.06 c.p.m. $/ \mu \mathrm{g}$ DNA with an average recovery of $405 \mu \mathrm{g}$ DNA/uterus). The values are mean \pm s.d. for 6 observations. 
oestradiol, compete with it for its receptor protein more efficiently than other steroid hormones. It is hoped that further analysis might show whether HPMF can compete with oestrogen for its receptor and whether it can inhibit other indicators of oestrogen-induced growth such as DNA synthesis, water inhibition and polysome synthesis.

We thank Organon Ltd, Newhouse, Lanarkshire, for the gift of HPMF and Dr G. F. Woods for arranging the gift and for helpful discussions.

\section{References}

Axelson, M. \& Setchell, D.R. (1981) Conjugation of lignans in human urine. FEBS Letters 123, 337-342.

Aziz, S. \& Knowler, J.T. (1978) Characterisation of uterine hnRNA and the effect of oestradiol-17 $\beta$ on its synthesis. Biochem. J. 172, 587-593.

Knowler, J.T. \& Smellie, R.M.S. (1971) The synthesis of RNA in immature uterus responding to oestradiol. Biochem. J. 125, 605-614.

Knowler, J.T., Borthwick, N.M. \& Smellie, R.M.S. (1975) Early effects of oestrogen on the transcription of uterine ribonucleic acid. Biochem. Soc. Trans. 3, 1177-1180.

Setchell, K.D., Lawson, A.M., Mitchell, F.L., Adlercreutz, H., Kirk, D.H. \& Axelson, M. (1980)
Lignans in man and animal species. Nature, Lond. 288, 740-742.

Stitch, S.R., Toumba, J.K., Groen, M.B., Funke, C.W., Leemhuis, J., Vink, J. \& Woods, G.F. (1980) Excretion, isolation and structure of a new phenolic constituent of female urine. Nature, Lond. 287 , 738-740.

Waters, A.P. \& Knowler, J.T. (1981) A comparison of the effects of oestrogen and tamoxifen on the synthesis of uterine RNA in immature rats. J. Steroid Biochem. 14, 625-630.

Received 19 March 1982 